\title{
Chromosomal Heterogeneity among Various Strains of Spiroplasma citri
}

\author{
FENGCHUN YE, ${ }^{1}$ FRÉDÉRIC LAIGRET, ${ }^{2 *}$ PATRICIA CARLE, ${ }^{2}$ AND \\ JOSEPH MARIE BOVÉ ${ }^{2}$ \\ Department of Plant Pathology, Oklahoma State University, Stillwater, Oklahoma $74078^{1}$ and \\ Laboratoire de Biologie Cellulaire et Moléculaire, Institut National de la Recherche \\ Agronomique and Université de Bordeaux II, 33883, \\ Villenave d'Ornon Cedex, France ${ }^{2}$
}

\begin{abstract}
The genomes of various Spiroplasma citri strains were digested with several restriction enzymes, and the fragments were analyzed by pulsed-field gel electrophoresis. Polymorphism of the restriction patterns was observed. The genome sizes of the strains obtained when we added the restriction fragment sizes ranged from 1,650 to $1,910 \mathrm{kbp}$. Physical and genetic maps of 12 strains were constructed by using several DNA probes as genetic markers. The relative positions of mapped loci were conserved in most of the strains; the main differences were differences in the order and number of restriction sites and differences in the sizes of certain fragments. The distribution of viral sequences, which occur at multiple sites in the $S$. citri genome and are homologous to the sequences of $S$. citri virus SpV1 strains R8A2B and S102, was also studied.
\end{abstract}

Since the first culture of Spiroplasma citri (38), the helical mollicute that causes stubborn disease of citrus, several hundred isolates of this agent have been obtained. These organisms have been isolated from infected citrus trees and herbaceous hosts and from insect vectors of the spiroplasmas, such as the leafhopper Circulifer haematoceps (15). The major characteristics of $S$. citri include helical morphology, motility, small genome size, and low genome $\mathrm{G}+\mathrm{C}$ content ( $26 \mathrm{~mol} \%$ ).

Phylogenetic studies have shown that spiroplasmas, like all other organisms in the class Mollicutes, arose from the phylum of gram-positive bacteria by successive elimination of genomic DNA $(46,53,54)$.

Physical and genomic maps of several mollicutes, including S. citri $\mathrm{R} 8 \mathrm{~A} 2^{\mathrm{T}}$ ( $\mathrm{T}=$ type strain), have been published previously $(2,12,21,22,29,31,43,47-50,55,56)$. Polymorphism has been observed among strains of the same species with several organisms, including Mycoplasma mycoides, Mycoplasma hominis, Mycoplasma hyopneumoniae, and Ureaplasma urealyticum $(16,22,31,36)$, suggesting that these organisms belong to a group of prokaryotes that exhibits a high evolution rate, as suggested previously by $16 \mathrm{~S}$ rRNA sequence data (54).

Several previous studies revealed that polymorphism could be found in several $S$. citri strains isolated from various hosts in different geographical areas; these studies were studies in which the researchers used serology, protein electrophoretic profiles, restriction fragment length polymorphism, and spiralin gene nucleotide sequences $(4,5,25)$. A striking feature of the $S$. citri genome is that it contains multiple copies of sequences homologous to the spiroplasma virus SpV1 sequence $(34,35,56)$ and that the number and distribution of these sequences are variable from one strain to another (34).

In order to investigate further the chromosomal heterogeneity of various $S$. citri strains, we analyzed the genomic DNAs of these organisms by performing restriction enzyme digestion followed by pulsed-field gel electrophoresis (PFGE). Physical

* Corresponding author. Mailing address: Laboratoire de Biologie Cellulaire et Moléculaire, INRA et Université de Bordeaux II, BP81, 71 Avenue Edouard-Bourleaux, 33883 Villenave d'Ornon Cedex, France. Phone: 33568431 50. Fax: 33568431 59. Electronic mail address: laigret@bordeaux.inra.fr. and genomic maps of 12 strains were constructed, and the relative positions of restriction sites and genetic markers, including virus-like sequences, were compared.

\section{MATERIALS AND METHODS}

S. citri strains. The 12 strains of $S$. citri which we studied are listed in Table 1 . These strains were grown at $32^{\circ} \mathrm{C}$ in BSR medium (6). BSR medium (B medium supplemented with sorbitol and reduced) was derived from B medium of Ernø and Stipkovits (14) by adding $70 \mathrm{~g}$ of sorbitol per liter, decreasing the concentration of horse serum from 20 to $10 \%$, and omitting fresh yeast extract and DNA. The strains were identified as $S$. citri strains by an enzyme-linked immunosorbent assay in which a polyclonal antibody directed against $S$. citri $\mathrm{R} 8 \mathrm{~A} 2^{\mathrm{T}}$ was used (40).

Preparation and restriction of $S$. citri genomic DNA. $S$. citri genomic DNAs were prepared, included in low-melting-point agarose plugs, and digested with restriction endonucleases $A p a \mathrm{I}, B s s \mathrm{HII}$, and Sall (Gibco/BRL, Gaithersburg, Md; Biolabs, Beverly, Mass.) as described previously $(30,56)$. The S. citri DNA was separated by PFGE by using a transverse alternating field electrophoresis system (Geneline II; Beckman, Palo Alto, Calif.) under the following conditions. For restricted genomic DNA, the pulse times were as follows; $45 \mathrm{~s}, 6 \mathrm{~h}(370 \mathrm{~mA})$; $1 \mathrm{~min}, 6 \mathrm{~h}(390 \mathrm{~mA})$; and $45 \mathrm{~s}, 6 \mathrm{~h}(390 \mathrm{~mA})$. And for undigested genomic DNA the pulse times were as follows: $1 \mathrm{~min}, 12 \mathrm{~h}(350 \mathrm{~mA}) ; 2 \mathrm{~min}, 12 \mathrm{~h}(370 \mathrm{~mA})$; and $3 \mathrm{~min}, 12 \mathrm{~h}(390 \mathrm{~mA})$. The working buffer used was $0.25 \times$ TBE ( $1 \times$ TBE is 0.089 $\mathrm{M}$ Tris-borate, $0.089 \mathrm{M}$ boric acid, and $0.002 \mathrm{M}$ EDTA), and the migration temperature was maintained at $8^{\circ} \mathrm{C}$.

$S$. citri genomic DNAs from various strains were also extracted from cultured cells as described by Marmur (24), and about $2 \mu \mathrm{g}$ of the DNA from each strain was digested overnight with EcoRI and HindIII by using the procedure recommended by the manufacturer (Gibco/BRL)

Mapping of the $S$. citri genomes. Restricted $S$. citri DNAs were blotted onto nylon membranes (Hybond $\mathrm{N}^{+}$; Amersham, Burckinghamshire, United Kingdom) with $0.4 \mathrm{~N} \mathrm{NaOH}$ by using the standard alkaline Southern blotting procedure $(32,42)$, except that the PFGE gels were previously treated twice with 0.25 $\mathrm{N} \mathrm{HCl}$ for $10 \mathrm{~min}$. The orders of the restriction fragments of various $S$. citri genomes were determined by hybridization with the probes listed in Table 2 . Some randomly cloned DNA fragments (fragments $\mathrm{S} 2, \mathrm{~S} 4$, and p6) from $S$. citri $\mathrm{R} 8 \mathrm{~A} 2^{\mathrm{T}}$ were also used as probes to connect the restriction fragments. The DNA probes were labelled with $\left[\alpha-{ }^{32} \mathrm{P}\right] \mathrm{dATP}$ by random priming with a Random Primers DNA Labelling System (Gibco/BRL).

\section{RESULTS}

Polymorphism at the rrn locus. $S$. citri has only one rRNA operon (rrn) (19). In order to study the level of heterogeneity at the single $r n$ locus in various $S$. citri strains, we hybridized the EcoRI- and HindIII-restricted S. citri genomic DNAs with the following two plasmid probes: pR136 containing the $16 \mathrm{~S}$ ribosomal DNA (rDNA) of S. citri (23) and pMC5 containing 
TABLE 1. S. citri strains studied

\begin{tabular}{|c|c|c|c|c|}
\hline Strain & Geographic origin & Animal or plant origin & Source $(s)^{a}$ & Reference \\
\hline $\mathrm{R} 8 \mathrm{~A} 2^{\mathrm{T}}\left(=\mathrm{ATCC} 27556^{\mathrm{T}}\right)$ & Tadla, Morocco & Washington navel orange leaves & ATCC, LBCM & 39 \\
\hline $\mathrm{R} 8 \mathrm{~A} 2-\mathrm{B}$ & Tadla, Morocco & Washington navel orange leaves & LMM & 27 \\
\hline C-189 (= ATCC 27665) & California & Madame Vinous orange leaves & ATCC, UC & 17 \\
\hline Hinckley & California & Hinckley orange leaves & LBCM & 3 \\
\hline MH & Gharb, Morocco & Washington navel orange leaves & LBCM & 37 \\
\hline M4 & Rabat, Morocco & Periwinkle leaves & LBCM & 6 \\
\hline Corse & Corsica, France & Leafhopper & LBCM & 15 \\
\hline Israel (= NCPPB 2565) & Israel & Valencia late orange seeds & NCPBB, JII & 13 \\
\hline 78 & Misis, Turkey & Washington navel orange leaves & LBCM & 45 \\
\hline Alc-254 & Alcanar, Spain & Washington navel orange fruits & LBCM & 3 \\
\hline Aspl (= NCPPB 3095) & Israel & Washington navel orange leaves & NCPBB, JII & 44 \\
\hline Palmyre & Palmyre, Syria & Leafhopper & LBCM & 15 \\
\hline
\end{tabular}

${ }^{a}$ ATCC, American Type Culture Collection, Rockville, Md.; LBCM, Laboratoire de Biologie Cellulaire et Moléculaire, Institut National de la Recherche Agronomique, Villenave d'Ornon, France; LMM, Laboratory of Molecular Microbiology, Frederick, Md;; UC, University of California, Riverside; NCPPB, National Collection of Plant Pathogenic Bacteria, Ministry of Agriculture, Food and Fisheries, Harpenden, United Kingdom; JII, John Innes Institute, Norwich, United Kingdom.

the $3^{\prime}$ end of the 16S rRNA gene and the entire $23 \mathrm{~S}$ and $5 \mathrm{~S}$ rRNA genes of Mycoplasma capricolum (1). The first probe was chosen because it includes the highly conserved EcoRI site in the middle of the $16 \mathrm{~S}$ rDNA, and the second probe was chosen because it includes two relatively conserved HindIII sites in the 23S rDNA (19).

As shown in Fig. 1, hybridization between the EcoRI- and HindIII-digested DNAs and the rDNA probes revealed strain polymorphism. Strains R8A2 ${ }^{\mathrm{T}}$, R8A2-B, and C-189 (Fig. 1, lanes 1,2 , and 6 , respectively) produced the same patterns with both enzymes. The other nine strains differed from these three strains in both their EcoRI fragment patterns and their HindIII fragment patterns; they produced identical EcoRI profiles but could be distinguished by their HindIII patterns. Strains Corse and Hinckley (lanes 4 and 10) produced the same HindIII pattern, which was distinct from the HindIII patterns of strains MH, M4, Israel, Asp1, 78, and Alc-254 (lanes 5, 12, 7, 3, 8, and 11 respectively). In addition, the rDNA gene hybridization pattern of HindIII-restricted strain Palmyre DNA (lane 9) was quite different from the patterns produced by all other strains.

Genome sizes and restriction patterns. Nonrestricted genomic DNAs of the $12 \mathrm{~S}$. citri strains were analyzed by PFGE and were compared with the yeast chromosome, which was used as a size marker. We found that the genome sizes of the various strains ranged from 1,600 to $1,900 \mathrm{kbp}$ (data not shown). In order to determine the genome sizes more accurately, the genomic DNAs were cleaved with restriction enzymes $A p a \mathrm{I}, B s s \mathrm{HII}$, and $S a l \mathrm{I}$, and the resulting fragments were separated by PFGE. The restriction patterns are shown in Fig. 2 . The sizes of the genomes were calculated by adding the sizes of the restriction fragments; the resulting values, as well as the numbers of restriction sites, are shown in Table 3 . The genome of strain $\mathrm{R} 8 \mathrm{~A} 2^{\mathrm{T}}$ was almost $1,820 \mathrm{kbp}$ long, $50 \mathrm{kbp}$ longer than the genome of R8A2-B or C-189. The two Morocco strains, strains $\mathrm{MH}$ and $\mathrm{M} 4$, not only had identical genome sizes $(1,820$ $\mathrm{kbp})$ but also produced the same restriction patterns. The same was true for strains Israel and Asp1, which had the smallest genomes $(1,650 \mathrm{kbp})$. The genome of strain Alc-254 was the largest genome $(1,910 \mathrm{kbp})$.

On the basis of the restriction profiles, it appeared that differences occurred preferentially in certain restriction fragments. For example, the smaller the genome, the smaller fragment ApA was. Strains R8A2 ${ }^{\mathrm{T}}$, R8A2-B, and C-189 produced similar patterns except that fragment ApA or BsC of $\mathrm{R} 8 \mathrm{~A} 2^{\mathrm{T}}$ was $50 \mathrm{kbp}$ longer. With $A p a \mathrm{I}$ or BssHII, the patterns obtained for strains $\mathrm{MH}, \mathrm{M} 4$, Israel, Asp1, 78, and Alc-254 were very similar (Fig. 2, lanes 5, 6, 8, 11, 9, and 10, respectively). With SalI, a single fragment was obtained for strains MH, M4, and Alc-254; double digestion with $A p a I$ and SalI or BssHII and SalI revealed that the genomes of these three strains were not

TABLE 2. Probes used for $S$. citri genome mapping

\begin{tabular}{|c|c|c|c|c|}
\hline Probe no. & Gene(s) & Product(s) & Source & Reference \\
\hline 1 & $\begin{array}{l}\text { pss } B \text {-tsf-x-spi- } \\
\text { pfkA-pyk }\end{array}$ & $\begin{array}{l}\text { Ribosomal protein S2, EF-Ts, protein X, spiralin, 6-phosphofructokinase, } \\
\text { pyruvate kinase }\end{array}$ & S. citri & 9 \\
\hline 2 & $f i b$ & Fibrillar protein & S. citri & 52 \\
\hline 3 & $m n$ & $16 \mathrm{~S}$ rRNA & S. citri & 23 \\
\hline 4 & $r n$ & $16 \mathrm{~S}, 23 \mathrm{~S}$, and $5 \mathrm{~S}$ rRNAs & M. capricolum & 1 \\
\hline 5 & pyrG-purA-purB & CTP synthetase, adenylosuccinate synthetase and lyase & S. citri & 10 \\
\hline 6 & rpoD & RNA polymerase $\sigma$ subunit & S. citri & 56 \\
\hline 8 & $\operatorname{trp} T-\operatorname{trp} U-\operatorname{ser} T$ & $\operatorname{tRNA}^{\operatorname{Trp}}(\mathrm{UCA}), \mathrm{tRNA}^{\mathrm{Tr}}(\mathrm{CCA}), \mathrm{tRNA}^{\mathrm{Ser}}(\mathrm{CGA})$ & S. citri & 11 \\
\hline 9 & $\operatorname{trn} B$ & 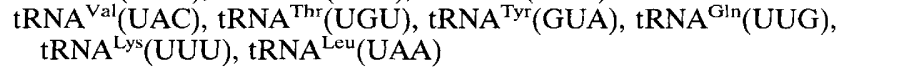 & S. citri & 10 \\
\hline 10 & SpV1-S102 & Spiroplasma virus 1 & S. citri & 35 \\
\hline 11 & SpV1-R8A2B & Spiroplasma virus 1 & S. citri & 33 \\
\hline 12 & $\mathrm{p} 6$ & Unknown & S. citri & This study \\
\hline 13 & $\mathrm{~S} 2$ & Unknown & S. citri & This study \\
\hline 14 & S4 & Unknown & S. citri & This study \\
\hline
\end{tabular}


A

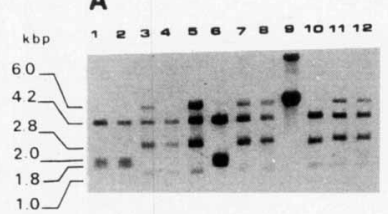

FIG. 1. Southern blot of genomic DNAs from $12 \mathrm{~S}$. citri strains digested with EcoRI and hybridized with probe 3 (B) or digested with HindIII and hybridized with probe 4 (A). Lanes 1. R8A2T; lanes 2, R8A2-B; lanes 3, Aspl; lanes 4, Corse; lanes 5, MH; lanes 6, C-189; lanes 7, Israel; lanes 8, 78; lanes 9, Palmyre; lanes 10, Hinckley; lanes 11, Alc-254; lanes 12, M4.

cleaved by SalI (data not shown). Similarly, the genomic DNA of strain Hinckley was not cut by BssHII. The restriction pattern of strain Palmyre was completely different from the restriction patterns of all other strains.

Construction and comparison of genomic maps. In order to compare the genomes of the 12 strains, we constructed physical and genetic maps for these strains. Restriction fragments of each strain generated by enzymes $A p a \mathrm{I}$ and $B s s \mathrm{HII}$ were aligned and linked by hybridization with several probes. Examples of the hybridization experiment results are shown in Fig. 3. When fib was used as a probe, extensive polymorphism was observed. This polymorphism correlated with the variation in the size of fragment ApA. For strain Alc-254 (Fig. 3, lane 10), two hybridization signals were obtained after digestion with $A p a \mathrm{I}$ or $B s s$ HII. Since $f b$ does not contain any restriction site for $A p a I$ or BssHII, it is likely that this gene is duplicated in the chromosome of strain Alc-254. When $\mathrm{p} 6$ was used as a probe, the hybridization patterns obtained were more conserved among strains. The DNA fragment of p6 contains an ApaI restriction site, and this site was present in all of the strains tested since in all instances two $A p a I$ restriction fragments were obtained when 06 was used as a probe. The sizes of the BssHII fragments that hybridized with $\mathrm{p} 6$ appeared to be almost identical for all of the strains tested except strain Hinckley (whose DNA is not cut by BssHII) and strain Palmyre.

Eleven genetic markers were located on the restriction maps (Fig. 4). We did not construct maps for SalI fragments because
TABLE 3. Genome sizes of 12 S. citri strains and numbers of ApaI, BssHII, and Sall restriction sites

\begin{tabular}{lcccr}
\hline \multicolumn{1}{c}{ Strain(s) } & $\begin{array}{c}\text { Genome sizc } \\
(\mathrm{kbp})\end{array}$ & \multicolumn{3}{c}{ No. of restriction sites for: } \\
\cline { 3 - 5 } & Apal & BssHIl & Sal \\
\hline R8A2 $^{\text {T }}$ & $\mathbf{1 , 8 2 0}$ & 9 & 9 & 8 \\
R8A2-B, C-189 $_{\text {Corse }}$ & $\mathbf{1 , 7 7 0}$ & 9 & 9 & 8 \\
Hinckley & 1,870 & 9 & 7 & 10 \\
Alc-254 & 1,840 & 8 & 0 & 10 \\
78 & 1,910 & 10 & 7 & 0 \\
MH, M4 & 1,760 & 9 & 6 & 9 \\
Israel, Asp1 & 1,820 & 9 & 7 & 0 \\
Palmyrc & 1,650 & 9 & 7 & 10 \\
\hline
\end{tabular}

the genomes of three strains were not cut by this enzyme. The maps of strains R8A2 ${ }^{\mathrm{T}}, \mathrm{R} 8 \mathrm{~A} 2-\mathrm{B}$, and C-189 were almost identical except that fragment $\mathrm{ApA}$ of $\mathrm{R} 8 \mathrm{~A} 2^{\mathrm{T}}$ was $50 \mathrm{kbp}$ larger than the corresponding ApA fragments of the two other strains. For the following strains, the genomes within a pair were similar, but differed from the genomes of the other organisms: $\mathrm{MH}$ and M4; Israel and Asp1; and 78 and Alc-254. Strain Hinckley had no Bss HII site, but its genome reassembled the genome of strain Corse on the basis of the ApaI restriction map. In contrast, the map of strain Palmyre was different from the maps of all other strains.

Even though the different strains exhibited obvious chromosomal heterogeneity, it seemed that the gene order for most genes examined was conserved in all of the strains. Certain restriction sites were also conserved. For instance, the ApaI site connecting fragment ApC to fragment ApF or ApG (depending on the strain) and contained in probe $\mathrm{p} 6$ was present in the genomes of all of the strains (Fig. 4). Similarly, the two adjacent $B s s$ HII sites that accounted for approximately 150 $\mathrm{kbp}$ (fragment BsE or BsF) were conserved in most strains. The same was true for fragments $\mathrm{ApB}$ and BsA carrying the $d n a A$ gene and the chromosomal replication origin (oriC).

Viral sequences in the genome. Most strains of $S$. citri are infected with one or several strains of SpV1, a rod-shaped virus

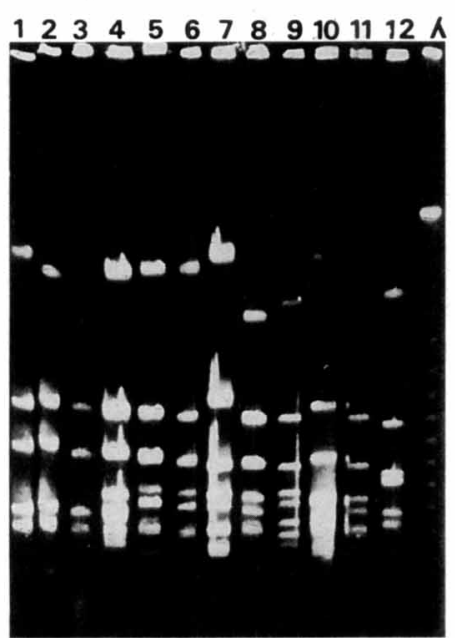

Apal

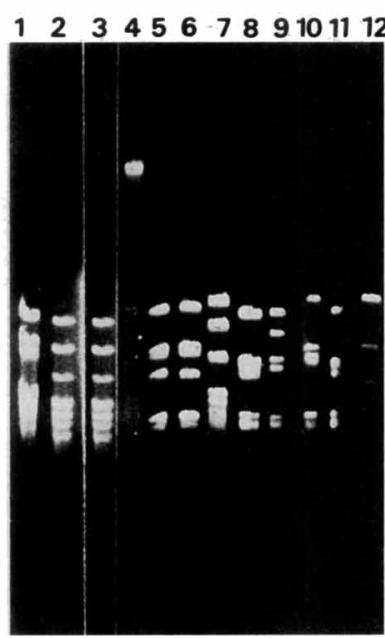

Bss H II

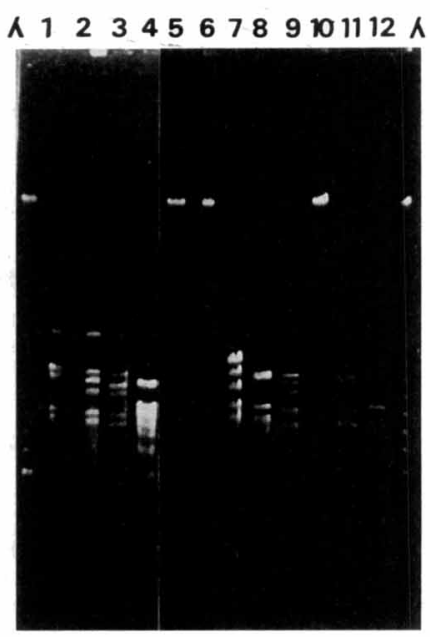

Sall

FIG. 2. PFGE of restricted genomic DNAs from various $S$. citri strains. Lanes 1, R8A2T; lanes 2, R8A2-B; lanes 3, C-189; lanes 4, Hinckley; lanes 5 , MH; lanes 6, M4; lanes 7, Corse; lanes 8, Israel; lanes 9, 78; lanes 10, Alc-254; lanes 11, Asp1; lanes 12, Palmyre; lanes $\lambda$, size marker (lambda DNA ladder). 


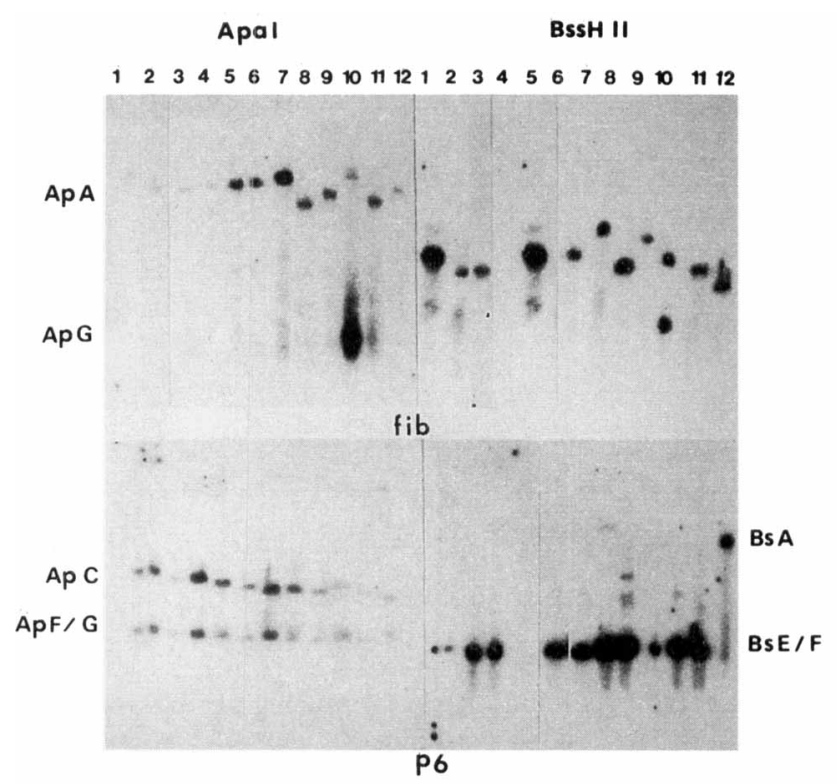

FIG. 3. Southern blots of gels after PFGE of ApaI- or BssHII-restricted genomic DNAs from various $S$. citri strains with probe $2(f i b)$ and probe 12 (p6). Lanes 1, R8A2 ${ }^{\mathrm{T}}$; lanes 2, R8A2-B; lanes 3, C-189; lanes 4, Hinckley; lanes 5, MH; lanes 6, M4; lanes 7, Corse; lanes 8, Israel; lanes 9, 78; lanes 10, Alc-254; lanes 11, Asp1; lanes 12, Palmyre.

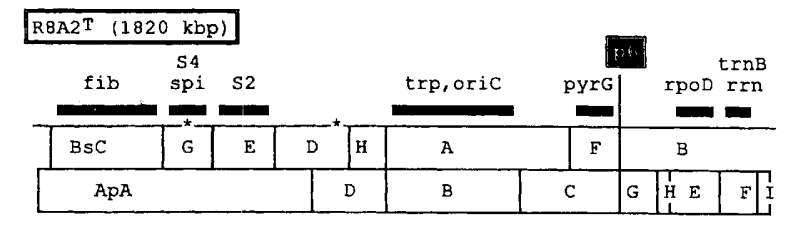

$\mathrm{R} 8 \mathrm{~A} 2-\mathrm{B}, \mathrm{C}-189 \quad(1770 \mathrm{kbp})$
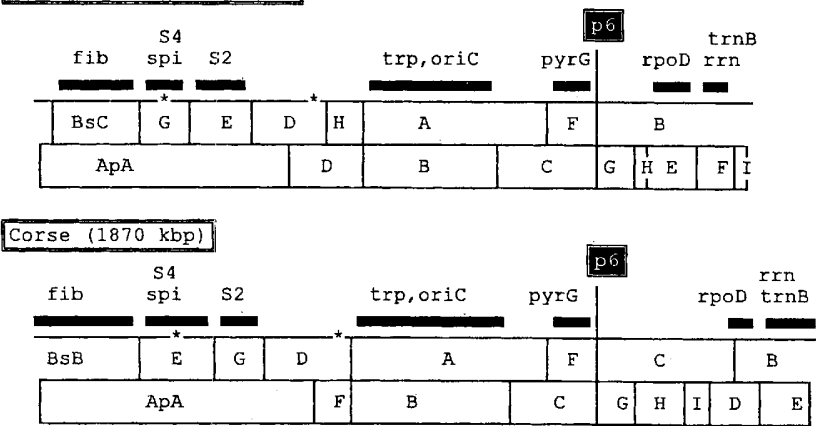

Hinckley (1840 klsp)
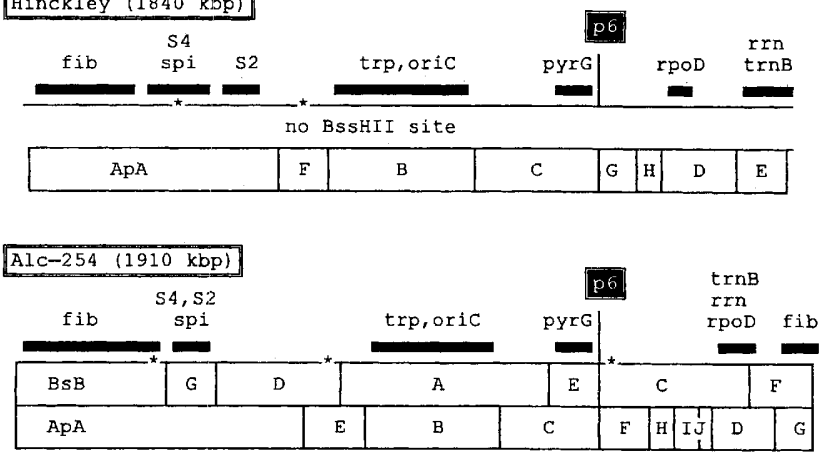

with single-stranded circular DNA (33-35). The genome of SpV1 strain R8A2B has been sequenced and contains 8,273 bases (33). A striking feature of $S$. citri is the presence in its genome of multiple sequences homologous to $\mathrm{SpV} 1$ sequences (34, 35, 56). SpV1 strains R8A2B and S102 are two distinct isolates. The genomes of these viruses are similar in size (about $8 \mathrm{kbp}$ ) but exhibit almost no cross hybridization (35). Sequences homologous to one of the two viral genomes were detected in the chromosomes of all of the $S$. citri strains tested (35).

The $S$. citri chromosome contains more sequences that are homologous to SpV1 strain R8A2B sequences than sequences that are homologous to $\mathrm{SpV} 1$ strain $\mathrm{S} 102$ sequences $(35,56)$. As shown in Fig. 5, most chromosomal restriction fragments reacted with the SpV1 strain $\mathrm{R} 8 \mathrm{~A} 2 \mathrm{~B}$ probe, suggesting that viral sequences may be scattered along the whole genome. In contrast, SpV1 strain S102 sequences were present in only two or three sites on the $S$. citri chromosome (data not shown). These sequences were located on the genomic maps, and one was located in the vicinity of the spiralin gene (spi) in all of the strains tested.

\section{DISCUSSION}

Polymorphism of $S$. citri rDNA genes was correlated with chromosomal heterogeneity; in other words, the strains that
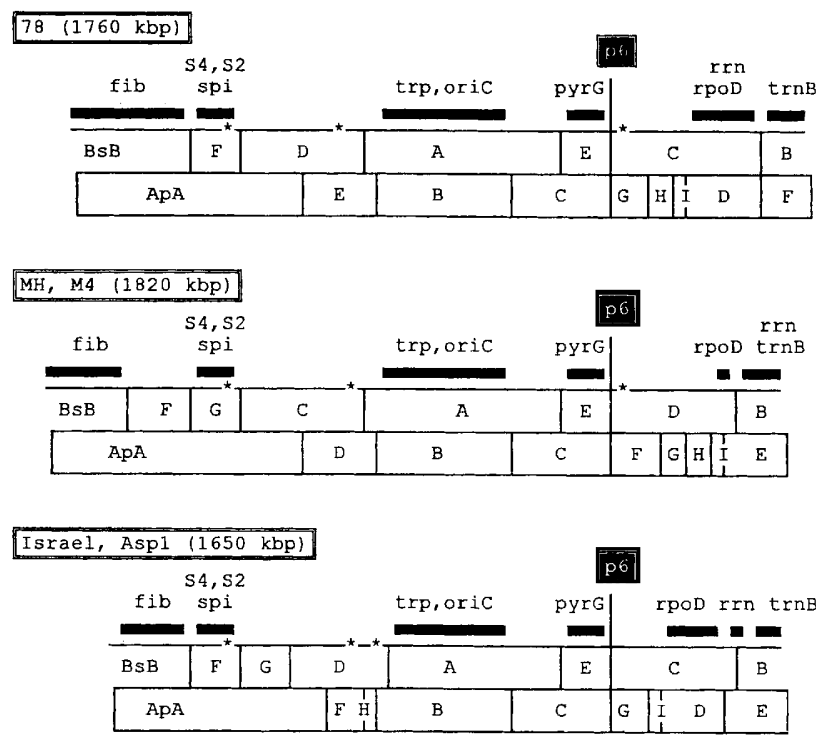

\section{Palmyre (1820 kbp)}

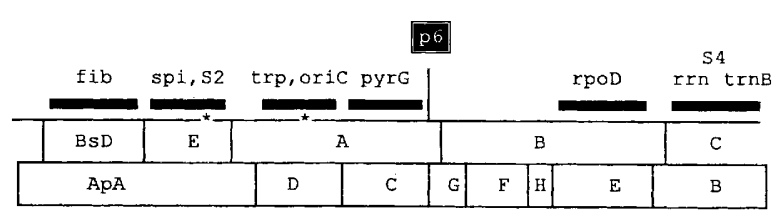

FIG. 4. Physical and genetic maps of various $S$. citri strains obtained with restriction enzymes ApaI (Ap) and BssHII (Bs). The positions of several gene markers are indicated at the top of each map. Abbreviations: $\operatorname{trp}, \operatorname{trp} T$-trpU-serT; pyrG, pyrG-purA-purB. The position of p6 is strongly conserved. The asterisks indicate the positions of Spv1-S102-like sequences. 


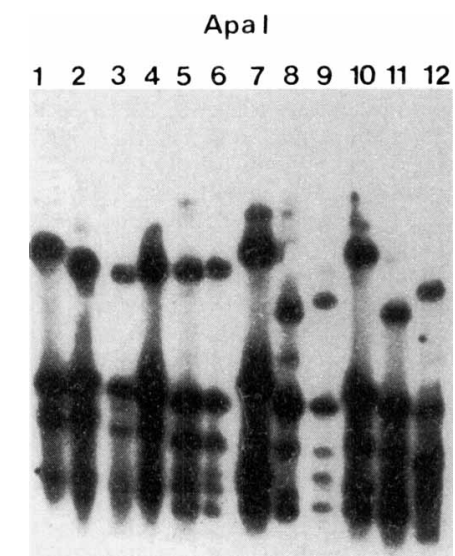

FIG. 5. Hybridization of ApaI-restricted $S$. citri genomic DNA fragments with the SpV1-R8A2B probe. Lane 1, R8A2 ${ }^{\mathrm{T}}$; lane 2, R8A2-B; lane 3, C-189; lane 4, Hinckley; lane 5, MH; lane 6, M4; lane 7, Corse; lane 8, Israel; lane 9, 78; lane 10, Alc-254; lane 11, Asp1; lane 12, Palmyre.

had similar genomic maps produced identical hybridization patterns with rDNA probes. This was the case for strains R8A2 ${ }^{\mathrm{T}}, \mathrm{R} 8 \mathrm{~A} 2-\mathrm{B}$, and C-189, which produced identical rDNA profiles and very similar PFGE patterns; the only difference was an ApA fragment that was $50 \mathrm{kbp}$ shorter in R8A2-B and C-189 than in $\mathrm{R} 8 \mathrm{~A} 2^{\mathrm{T}}$. In a previous study, $S$. citri strains were divided into groups on the basis of the mobility of spiralin (the major protein component of the membrane) during polyacrylamide gel electrophoresis (4). As a general rule, the strains that produced identical rDNA profiles and similar PFGE patterns contained spiralins that had the same apparent molecular weight. Genomic variations did not affect serologic reactivity against an antiserum to type strain R8A2. The only difference that has been observed is the lack of reactivity in Western blots of the spiralin of strain Palmyre to a monoclonal antibody against $S$. citri Israel (4). This lack of reactivity was related to the amino acid sequence of the spiralin itself (4).

The genome sizes of the $S$. citri strains examined ranged from 1,650 to $1,910 \mathrm{kbp}$. This genome size polymorphism may have resulted from genomic rearrangements (deletions or duplications). One example is the 50-kbp difference between the genome of high-passage strain $\mathrm{R} 8 \mathrm{~A} 2^{\mathrm{T}}$ and the genome of lowpassage strain $\mathrm{R} 8 \mathrm{~A} 2-\mathrm{B}$; these two strains originated from the same $S$. citri isolate, and the difference in genome sizes occurs between the $f i b$ and spi loci in fragment ApA, a region where most of the variations in size were observed. Other examples of rearrangements were found in the genomes of strains $\mathrm{MH}, \mathrm{M} 4$, Israel, Asp1, 78, and Alc-254. The genome of strain Alc-254 was the largest genome examined $(1,910 \mathrm{kbp})$, and the genomes of strains Asp1 and Israel were the smallest $(1,650 \mathrm{kbp})$. Between these two extremes were the genomes of strains 78 , $\mathrm{MH}$, and $\mathrm{M} 4(1,760,1,820$, and $1,820 \mathrm{kbp}$, respectively). A comparison of the genomic maps revealed that approximately $100 \mathrm{kbp}$ in fragment ApA of strain $78,80 \mathrm{kbp}$ in the same region of strains $\mathrm{MH}$ and $\mathrm{M} 4$, and $250 \mathrm{kbp}$ in the genomes of strains Israel and Asp1 were missing. These deletions accounted fro the differences in the genome sizes of these strains. In addition, it seemed that part of fragment ApA of strain Alc-254, which contained $f i b$, was duplicated.

Chromosomal heterogeneity of $S$. citri strains was observed not only in genome size, but also in restriction patterns. Compared with other genomic regions, the region containing the chromosomal replication origin (oriC) seemed to be the most stable region. In contrast, the large region of fragment ApA, corresponding to the putative replication terminus, was apparently the most variable region. This seems to be consistent with the results of studies on enterobacteria which suggested that genes far away from oriC have a higher mutation rate than genes near oriC (41).

We have reported previously that $\mathrm{SpV} 1$ strain $\mathrm{R} 8 \mathrm{~A} 2 \mathrm{~B}$ viral sequences are present in at least 17 locations on the $S$. citri $\mathrm{R} 8 \mathrm{~A} 2^{\mathrm{T}}$ genome (56). This seemed to be true for all of the strains tested in this study. Viral sequences are distributed all along the genome except for one region in the vicinity of the $r r n$ locus (56). Although nothing is known about the origin and role of these sequences, we speculate that their occurence in such large numbers has biological significance. In contrast, SpV1 strain S102 viral sequences were present in only two or three regions on the genome, and one was always located near the spi fragment.

Chromosomal rearrangements cannot account for all of the heterogeneity that was observed among the strains which we studied. Mutations may be responsible for a certain number of differences in restriction sites, especially when genome size and gene order are similar. DNA modifications, such as base methylation, may also be responsible for some of the differences observed. It has been observed previously that the number of SalI restriction sites is always much lower than the number predicted by statistics not only in S. citri, but also in Spiroplasma melliferum $(55,56), M$. mycoides, and $M$. capricolum (48-50). The same thing is true for $M$. hyopneumoniae when restriction enzyme $X h o I$ is used (16). It has been suggested that a Sall site (or a Xhol site) might be a methylation target in these organisms $(16,56)$. In this study we found that most $S$. citri strains which we examined have a low number of SalI sites and that three strains, MH, M4, and Alc-254, have no SalI sites. Because this is unlikely statistically, we propose that strains $\mathrm{MH}, \mathrm{M} 4$, and Alc-254 have a more efficient methylation system than the other strains which we studied. EcoRI sites might also be targets of modifications. Indeed, when the EcoRI-restricted DNAs of strains R8A2 ${ }^{\mathrm{T}}$, R8A2-B, and C-189 were hybridized with the rDNA probe, no $1.2-\mathrm{kb}$ DNA fragment was observed (Fig. 1), although such a fragment was identified in all other strains. Evidence that the sites had been modified came from a sequence analysis of the rDNA region of strain $\mathrm{R} 8 \mathrm{~A} 2^{\mathrm{T}}$; the single EcoRI and SalI sites were present in the sequence but were not revealed by a Southern blot analysis of the genomic DNA (18).

Our results support the contention that genome size is not an important marker for taxonomic classification of organisms in the class Mollicutes. Variations in genome size have been observed previously at the genus, species, and strain levels $(8$, $16,20,22,26,28,31,36,48,49,55)$. In $S$. citri the sizes of the smallest and largest genomes may differ by up to $260 \mathrm{kbp}$. Polymorphism in the genome sizes of different strains has also been observed in $M$. mycoides (31), U. urealyticum (36), $M$. hominis (22), and $M$. hyopneumoniae (16), as well as their walled eubacterial relatives Clostridium perfringens (7) and Clostridium acetobutylicum (51). It has been suggested on the basis of the results of $16 \mathrm{~S}$ rRNA sequence comparisons that mollicutes have high mutation rates $(53,54)$; in addition, these organisms seem to have significant rearrangements in large parts of their genomes. However, there is no biological trait which has been associated with variations in the genome size of S. citri strains.

\section{REFERENCES}

1. Amikam, D., S. Razin, and G. Glaser. 1982. Ribosomal RNA genes in mycoplasma. Nucleic Acids Res. 10:4215-4222.

2. Bautsch, W. 1988. Rapid physical mapping of the Mycoplasma mobile genome by two-dimensional field inversion electrophoresis techniques. Nucleic 
Acids Res. 16:11461-11468.

3. Bové, J. M. Unpublished data.

4. Bové, J. M., X. Foissac, and C. Saillard. 1993. Spiralins. Subcell. Biochem. 20:203-223.

5. Bové, J. M., F. Laigret, J. Renaudin, and C. Saillard. 1990. Polymorphism in various DNA sequences of the Spiroplasma citri genome. IOM Lett. 1:47-48.

6. Bové, J. M., J. C. Vignault, M. Garnier, C. Saillard, O. Garcia-Jurado, C. Bové, and A. Nhami. 1978. Mise en évidence de Spiroplasma citri, l'agent causal de la maladie du $\ll$ stubborn $\gg$ des agrumes, dans les Pervenche (Vinca rosea $\mathrm{L}$.) ornementales de la ville de Rabat, Maroc. C. R. Acad. Sci. Ser. D 286:57-60.

7. Canard, B., B. Saint-Joanis, and S. T. Cole. 1992. Genomic diversity and organization of virulence genes in the pathogenic anaerobe Clostridium perfringens. Mol. Microbiol. 6:1421-1429.

8. Carle, P., F. Laigret, J. G. Tully, and J. M. Bové. 1995. Heterogeneity of genome sizes within the genus Spiroplasma. Int. J. Syst. Bacteriol. 45:178181.

9. Chevalier, C., C. Saillard, and J. M. Bové. 1990. Organization and nucleotide sequences of the Spiroplasma citri genes for ribosomal protein S2, elongation factor Ts, spiralin, phosphofructokinase, pyruvate kinase and an unidentified protein. J. Bacteriol. 172:2693-2703.

10. Citti, C. 1992. Ph.D. thesis. Université de Bordeaux II, Bordeaux, France.

11. Citti, C., L. Maréchal-Drouard, C. Saillard, J. H. Weil, and J. M. Bové. 1992 Spiroplasma citri UGG and UGA tryptophan codons: sequences of the two tryptophanyl-tRNAs and organization of the corresponding genes. J. Bacteriol. 174:6471-6478.

12. Cocks, B. G., L. E. Pyle, and L. R. Finch. 1989. A physical map of the genome of Ureaplasma urealyticum $960^{\mathrm{T}}$ with ribosomal RNA loci. Nucleic Acids Res. 17:6713-6719.

13. Daniels, M. J., P. G. Markham, B. M. Meddins, A. K. Plaskitt, R. Townsend, and M. Bar-Joseph. 1973. Axenic culture of plant pathogenic spiroplasma. Nature (London) 244:523-524

14. Ernø, H., and L. Stipkovits. 1973. Bovine mycoplasmas: cultural and biochemical studies. II. Acta Vet. Scand. 14:450-463.

15. Fos, A. J. M. Bové, J. Lallemand, C. Saillard, J. C. Vignault, Y. Ali, P. Brun, and R. Vogel. 1986. La cicadelle Neoliturus haematoceps (Mulasant \& Rey) est le vecteur de Spiroplasma citri en Méditerranée. Ann. Inst. Pasteur/ Microbiol. 137A:97-107.

16. Frey, J., A. Haldimann, and J. Nicolet. 1992. Chromosomal heterogeneity of various Mycoplasma hyopneumoniae field strains. Int. J. Syst. Bacteriol. 42: 275-280.

17. Fudl-Allah, A. E.-S. A., E. C. Calavan, and E. C. K. Igwegbe. 1972. Culture of a mycoplasma-like organism associated with stubborn disease of citrus. Phytopathology 62:729-731.

18. Grau, O. Unpublished data.

19. Grau, O., F. Laigret, and J. M. Bové. 1990. Analysis of ribosomal RNA genes in two spiroplasmas, one acholeplasma and one unclassified mollicute. Zentralbl. Bakteriol. Suppl. 20:895-897.

20. Grau, O., F. Laigret, P. Carle, J. G. Tully, D. L. Rose, and J. M. Bové. 1991. Identification of a plant-derived mollicute as a strain of an avian pathogen, Mycoplasma iowae, and its implications for mollicute taxonomy. Int. J. Syst. Bacteriol. 41:473-478.

21. Krause, D. C., and C. B. Mawn. 1990. Physical analysis and mapping of the Mycoplasma pneumoniae chromosome. J. Bacteriol. 172:4790-4797.

22. Ladefoged, S. A., and G. Christiansen. 1992. Physical and genetic mapping of the genomes of five Mycoplasma hominis strains by pulsed-field gel electrophoresis. J. Bacteriol. 174:2199-2207.

23. Laigret, F., O. Grau, and J. M. Bové. 1990. Comparison of 16S rDNA sequences of various mollicutes. Zentralbl. Bakteriol. Suppl. 20:435-440.

24. Marmur, J. 1961. A procedure for the isolation of deoxyribonucleic acid from microorganisms. J. Mol. Biol. 3:208-218.

25. Mouches, C., T. Candresse, G. J. McGarrity, and J. M. Bové. 1983. Analysis of spiroplasma proteins: contribution to the taxonomy of group IV spiroplasma and the characterization of spiroplasma protein antigens. Yale $\mathrm{J}$. Biol. Med. 56:431-437.

26. Neimark, H. C., and C. S. Lange. 1990. Pulse-field electrophoresis indicates full-length mycoplasma chromosomes range widely in size. Nucleic Acids Res. 18:5443-5448.

27. Nur, I., G. Glaser, and S. Razin. 1986. Free and integrated plasmid DNA in spiroplasmas. Curr. Microbiol. 14:169-176.

28. Pyle, L. E., L. N. Corcoran, B. J. Cocks, A. D. Bergemann, J. C. Whitley, and L. R. Finch. 1988. Pulsed-field electrophoresis indicates larger than expected sizes for mycoplasma genomes. Nucleic Acids Res. 16:6015-6025.

29. Pyle, L. E., and L. R. Finch. 1988. A physical map of the genome of Mycoplasma mycoides subspecies mycoides $\mathrm{Y}$ with some functional loci. Nucleic Acids Res. 16:6027-6040.

30. Pyle, L. E., and L. R. Finch. 1988. Preparation and FIGE separation of infrequent restriction fragments from Mycoplasma mycoides DNA. Nucleic Acids Res. 16:226-228.

31. Pyle, L. E., T. Taylor, and L. R. Finch. 1990. Genomic maps of some strains within the Mycoplasma mycoides cluster. J. Bacteriol. 172:7265-7268.

32. Reed, K. C., and D. A. Mann. 1985. Rapid transfer of DNA from agarose gels to nylon membranes. Nucleic Acids Res. 13:7207-7221.

33. Renaudin, J., P. Aullo, J. C. Vignault, and J. M. Bové. 1990. Complete nucleotide sequence of the genome of Spiroplasma citri virus SpV1-R8A2 B. Nucleic Acids Res. 18:1293.

34. Renaudin, J., C. Bodin-Ramiro, J. C. Vignault, and J. M. Bové. 1990. Spiroplasmavirus 1: presence of viral DNA sequences in the spiroplasma genome. Zentralbl. Bakteriol. Suppl. 20:125-130.

35. Renaudin, J., and J. M. Bové. 1994. SpV1 and SpV4 spiroplasma viruses with circular, single-stranded DNA genomes, and their contribution to the molecular biology of spiroplasmas. Adv. Virus Res. 44:429-463.

36. Robertson, J. A., L. E. Pyle, G. W. Stemke, and L. R. Finch. 1990. Human ureaplasmas show diverse sizes by pulsed-field electrophoresis. Nucleic Acids Res. 18:1451-1455.

37. Saglio, P. 1975. Ph.D. thesis. Université de Bordeaux II, Bordeaux, France.

38. Saglio, P., D. Laflèche, C. Bonissol, and J. M. Bové, 1971. Culture in vitro des mycoplasmes associés au stubborn des agrumes et leur observation au microscope électronique. C. R. Acad. Sci. Ser. D 272:1387-1390.

39. Saglio, P., M. Lhospital, D. Laflèche, G. Dupont, J. M. Bové, J. G. Tully, and E. A. Freundt. 1973. Spiroplasma citri gen. and sp. n.: a mycoplasma-like organism associated with "stubborn" disease of citrus. Int. J. Syst. Bacteriol. 23:191-204.

40. Saillard, C., and J. M. Bové. 1983. Application of ELISA to spiroplasma detection and classification, p. 471-476. In S. Razin and J. G. Tully (ed.), Methods in mycoplasmology, vol. 1. Academic Press, New York.

41. Sharp, P. M., D. C. Shields, K. H. Wolfe, and W. H. Li. 1989. Chromosomal location and evolutionary rate variation in enterobacterial genes. Science 246:808-810.

42. Southern, E. M. 1975. Detection of specific sequences among DNA fragments separated by gel electrophoresis. J. Mol. Biol. 98:503-517.

43. Su, C. J., and J. B. Baseman. 1990. Genome size of Mycoplasma genitalium. J. Bacteriol. 172:4705-4707.

44. Townsend, R., P. G. Markham, K. A. Plaskitt, and M. J. Daniels. 1977. Isolation and characterization of a non-helical strain of Spiroplasma citri. J. Gen. Microbiol. 100:15-21.

45. Vignault, J. C., J. M. Bové, C. Saillard, R. Vogel, A. Farro, L. Venegas, W. Stemmer, S. Aoki, R. E. McCoy, A. S. Albeldawi, M. Larrue, O. Tuzcu, M. Ozsan, A. Nhami, M. Abassi, J. Bonfils, G. Moutous, A. Fos, F. Poutier, and G. Viennot-Bourgin. 1980. Mise en culture de spiroplasmes à partir de matériel végétal et d'insectes provenant des pays circum-méditerranéens et du Proche-Orient. C. R. Acad. Sci. Ser. D 290:775-778.

46. Weisburg, W. G., J. G. Tully, D. L. Rose, J. P. Petzel, H. Oyaizu, D. Yang, L. Mandelco, J. Sechrest, T. G. Lawrence, J. Van Etten, J. Maniloff, and C. R. Woese. 1989. A phylogenetic analysis of the mycoplasmas: basis for their classification. J. Bacteriol. 171:6455-6467.

47. Wenzel, R., and R. Herrmann. 1988. Physical mapping of the Mycoplasma pneumoniae genome. Nucleic Acids Res. 16:8323-8336.

48. Whitley, J. C. 1991. Ph.D. thesis. University of Melbourne, Melbourne, Australia.

49. Whitley, J. C., A. D. Bergemann, L. E. Pyle, B. G. Cocks, R. Youil, and L. R. Finch. 1990. Genomic maps of mycoplasmas and Tn916 insertion. Zentralbl. Bakteriol. Suppl. 20:47-55.

50. Whitley, J. C., A. Muto, and L. R. Finch. 1990. A physical map of Mycoplasma capricolum $\mathrm{Cal}$. kid with loci for all known tRNA species. Nucleic Acids Res. 19:399-400.

51. Wilkinson, S. R., and M. Young. 1993. Wide diversity of genome size among different strains of Clostridium acetobutylicum. J. Gen. Microbiol. 139:10691076.

52. Williamson, D. L., J. Renaudin, and J. M. Bové. 1991. Nucleotide sequence of the Spiroplasma citri fibril protein gene. J. Bacteriol. 173:4353-4362.

53. Woese, C. R. 1987. Bacterial evolution. Microbiol. Rev 51:221-271.

54. Woese, C. R., E. Stackebrandt, and W. Ludwig. 1985. What are mycoplasmas: the relationship of tempo and mode in bacterial evolution. J. Mol. Evol. 21:305-316.

55. Ye, F., F. Laigret, and J. M. Bové. 1994. A physical map of the prokaryote Spiroplasma melliferum and its comparison with the Spiroplasma citri map. C. R. Acad. Sci. 317:392-398.

56. Ye, F., F. Laigret, J. C. Whitley, C. Citti, L. R. Finch, P. Carle, J. Renaudin, and J. M. Bové. 1992. A physical and genomic map of the Spiroplasma citri genome. Nucleic Acids Res. 20:1559-1565.

57. Ye, F., J. Renaudin, J. M. Bové, and F. Laigret. 1994. Cloning and sequencing of the replication origin (oriC) of the Spiroplasma citri chromosome and construction of autonomously replicating artificial plasmids. Curr. Microbiol. 29:23-29. 